\title{
KUALITAS AIR TANAH DI TIGA IBUKOTA KECAMATAN (KUTOWINANGUN, PREMBUN DAN KUTOARJO) DAN KAITANNYA DENGAN SANITASI LINGKUNGAN SEKITAR
}

\author{
Oleb : \\ Sudarmadji dan Suyono
}

\begin{abstract}
Groundwater is a main source of water supply for domestic use in the urban area, especially for small towns. Due to man's activities water resources of waste water discharging into the environment combined with unproper environment sanitation system. Towns where are located in the coastal alluvial plain may prone to the groundwater pollution due their geological and geomorphological condition. Three small towns which a capital of sub-district, Kutowinangun, and Prembun (Kebumen District) and Kutoarjo (Purworejo District) were selected as study areas. The location of these three towns are close each other. The study purposes are to investigate groundwater quality in relation to the environment sanitation and public perception of the environment. The study was conducted by field observation, interviewing of respondents and laboratory analysis of water samples collected during the study. From the laboratory analysis it was found that some parameters used for the study bave sbown bigb level of concentration such as $\mathrm{NO}_{2}$, $\mathrm{NO}_{3}, \mathrm{SO}_{4}, \mathrm{Cl}, \mathrm{COD}, \mathrm{BOD}$ and coliform bacteria. This fact indicated that groundwater in the study area have been probably contaminated by buman activities, although it bas not exceeded the maximum permissible level of the standard. The degradation might cause by man's wastes and poor environmental sanitation of the area. The $\mathrm{NO}_{2}$ and $\mathrm{NO}_{3}$ level were higher in the center of towns, including those from roads might be sources of pollution of groundwater. Caliform bacteria were bigh in the towns, generally bigher than $2400 \mathrm{MPN} / 100 \mathrm{ml}$. The high COD levels are observed in Kutowinangun and Prembun (more than 25\% of samples having COD bigher than $10 \mathrm{mg} / \mathrm{l}$ ), whereas in Kutoarjo groundwater has a lower COD level. A similar situation was observed on BOD. Public perception to the environment were varies, nevertbeless they are who have a lower SLTP. level do not fully understand about the environment pollution.
\end{abstract}


Air tanab masib merupakan sumber air untuk keperluan sebari-bari bagi pen-

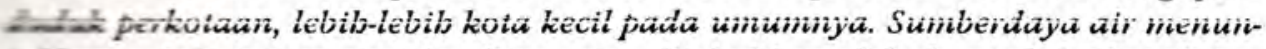
jubbin gejala penurunan kualitas yang disebabkan oleb dampak berbagai macam kegialan yang menghasilkan limbah dan sistem sanitasi lingkungan yang hereng baik. Daerab-daerab perkotaan yang terletak di dataran aluvial pantai Lesat merupakan daerab yang rawan terbadap pencemaran air tanab. Tiga ibubese kecamatan, yaitu Kutowinangun dan Prembun, Kabupaten Kebumen dan Faloarjo, Kabupaten Purworejo yang terletak saling berdekatan diteliti untuk mengesabui kualitas air tanab yang merupakan sumber air domestik penduduknya Alm kaitannya dengan kondisi sanitasi lingkungan serta persepsi masyarakat erbudap pencemaran sumber air tersebut.

Panelitian ini dilakukan dengan mengadakan pengamatan di lapangan, wa. uancara dengan penduduk serta analisis laboratorium terbadap sampel air ta. nab yang diambil. Ilasil analisis laboratorium menunjukkan gejala kualitas air L diga kota tersebut sudab memperlibatkan gejala penurunan, walaupun belum sampai melampaui ambang batas baku mutu air Golongan B. Penurunan tersetes terlibat dengan tingginya kadar $\mathrm{NO}_{2}, \mathrm{SO}, \mathrm{Cl}, \mathrm{COD}$ dan bakteri coli. Diperkirahes babwa tingginya kadar zat tersebut terkait dengan masalab limbab yang Alwang, yang didukung oleb sanitasi lingkungan yang masib belum baik. Kadar $\mathrm{NO}_{2}$ dan $\mathrm{NO}_{3}$ cenderung lebih tinggi di daerab pusat kola yang merupakan pusal altêritas penduduk, dibandingkan dengan daerah pinggir kota. Limbah dari aktireless kegiatan penduduk di pusat-pusat pelayanan umum, termasuk juga dari arana transportasi di jalan raya dapat merupakan sumber pencemar air tanab. Bakteri coli pada umumnya tinggi di ketiga kota yang diteliti, melebibi 2400 seNV/100 ml. Angka COD yang tinggi teramati di dalam air tanab Kutowinangun Les Prembun, lebih dari 25\% sampel di kedua kota ini memiliki COD diatas 10 $\mathrm{mg} / \mathrm{h}$, sedangkan di Kutoarjo relatif lebih rendah. Hal yang mirip didapatkan pada $B O D$. Persepsi penduduk terbadap masalab lingkungan umumnya beragam. sumun terlibat babwa penduduk dengan pendidikan di bawab SLTP masib belum mengerti atau kurang memperhatikan bal-hal yang terkait dengan pencemaran lingkungan.

\section{PENDAHULUAN}

Pencemaran air telah menyebabkan sumberdaya air menurun kualitasnya, schingga penggunaannya menjadi terbatas. Sumber pencemaran air yang potensial telah diidentifikasi, yaitu dari limbah domestik, limbah pertanian dan limbah pertambangan. Air di daerah perkotaan sangat rawan terhadap pencemaran, karena di daerah perkotaan padat penduduknya, padat permukim. annya serta banyak aktivitas penduduk yang menghasilkan limbah dilakukan di daerah itu. Sebagai akibat jumlah penduduk yang besar serta aktivitas yang dilakukannya, maka limbah yang dihasilkan juga cukup besar. Apabila di kota tersebut tidak didukung dengan sanitasi yang baik, maka air di dacrah yang bersangkutan akan mudah mengalami pencemaran. Banyak penelitian 
menunjukkan bahwa limbah industri dan limbah domestik dari kota besar dan pusat industri mengakibatkan menurunnya kualitas air sungai maupun air tanah.

Pertambahan penduduk menyebabkan perkembangan fisik kota yang cepat sejalan dengan itu penggunaan air bertambah dan jumlah kendaraan baik bermotor dan tidak bermotor pun bertambah. Penggunaan air untuk mandi, cuci dan WC akan menghasilkan limbah yang dibuang melalui sistem sanitasi atau ke permukaan tanah. Kendiaraan bermotor menghasilkan limbah berupa gas, ceceran oli dan sisa ban hasil gesekan dengan aspal. Apabila terjadi hujan akan terjadi limpasan dari atap, halaman rumah dan jalan, limpasan tersebut akan mengangkut limbah yang ada di daerah kota yang akhirnya masuk ke badan air (sungai, danau) dan sebagian masuk ke dalam tanah melalui proses infiltrasi, akhirnya mencapai air tanah. Pencemaran air tanah dapat pula terjadi melalui sistem peresapan limbah cair dari rumah tangga.

Di dataran rendah aluvial pantai Selatan Jawa Tengah seperti ketiga ibukota kecamatan Kutowinangun, Prembun, dan kecamatan Kutoarjo kondisi air tanahnya sangat dangkal, terutama pada waktu musim penghujan. Kondisi air tanah yang sedemikian itu sangat mudah mengalami pencemaran. Sistem drainase kota, tempat penimbunan sampah yang tidak sempurna, kendaraan andong (delman) yang ditarik kuda serta terbatasnya pengetahuan tentang lingkungan, memungkinkan timbulnya pencemaran air permukaan dan air tanah di ketiga kota tersebut. Ketiga ibukota kecamatan tersebut sangat menarik untuk diteliti; terutama pengaruh sistem sanitasi lingkungan terhadap kualitas air, khususnya air tanahnya di kota tersebut.
Penclitian ini berupaya mengungkap seberapa besar pengaruh limbah domestik dan sanitasi lingkungan tersebut tcrhadap kualitas air tanah dangkal di ketiga ibukota kecamatan Kutowinangun, Prembun dan Kutoarjo. Mengingat bahwa daerahnya terletak dataran aluvial pantai yang sering mengalami banjir, serta dijumpai kendaraan andong yang cukup banyak, sanitasi lingkungan yang kurang baik. Penelitian ini juga diarahkan untuk mengetahui apakah air tanah di daerah ini sudah atau belum mengalami pencemaran. Lebihlebih air tanah di daerah itu merupa. kan sumber air untuk keperluan domestik penduduk kota yang bersang. kutan.

\section{ii. TINJAUAN PUSTAKA}

Telah banyak diketahui bahwa pencemaran air, baik air sungai maupun air tanah disebabkan oleh berbagai macam limbah hasil sampingan kegiatan manusia. Sumber utama pencemaran air di daerah perkotaan adalah lim. bah domestik baik berupa limbah cair maupun limbah padat. Namun demikian selain kedua jenis limbah tersebut ada beberapa sumber pencemar lain yang cukup potensial menyumbangkan pencemar kepada sungai maupun air tanah, yaitu limbah dari fasilitas umum, seperti telah diteliti oleh Sudarmadji (1991) yang telah mengungkapkan pencemaran air tanah di Kotamadya Yogyakarta. Dalam penelitiannya terungkap bahwa daerah-daerah padat penduduk mempunyai kualitas air tanah yang kurang baik yang disebabkan olch tercemarnya air tanah tersebut oleh limbah domestik.

Perambatan pencemar dari permukaan tanah ke dalam tanah hingga mencapai air tanah ditentukan oleh ke- 
acbalan lapisan tanah di atas muka air anah serta jenis material penyusunma. Makin dangkal air tanah akan makin mudah tercemar, makin besar permcabilitas batuan cui alas muka dil tamah itu makin besar pula kemungkinan air tersebut tercemar (Todd, 1980).

Fencemaran air tanah telah lama di-ngkap oleh Yamamoto dan Hida (1974). Kedua peneliti telah mempelajari perkembangan kualitas air tanah dari tahun ke tahun di Mushashino Upband, Jepang. Kualitas air tanah ditelitinya dari tahun 1935 hingga tahun 1970. Dari penelitiannya diperoleh bohwa angka daya hantar listrik (DHL) dan klorida (Cl) menunjukkan kenaikan yang nyata dari tahun ke tahun. sngka DHL maupun Cl yang diperolehnya pada tahun 1970 sudah 2 kali lipat dibandingkan yang diperolehma pada tahun 1935. Hal tersebut dilatakannya sebagai dampak dari perabahan penggunaan lahan. Perkembangan untuk permukiman ternyata berubah secara mencolok, yang teramati pada tahun-tahun 1947, 1963, 1966 dan tahun 1971.

Dalam kaitannya dengan sanitasi Eingkungan, Sudarmadji (1989) mengungkapkan bahwa tingkat kesadaran lingkungan masyarakat di daerah pedesan masih sangat perlu untuk ditingkatkan. Di Dusun Banteng yang merupakan daerah sub-urban, sarana sanitasi yang dibuatkan oleh Pemerintah rang berupa sumur pompa tangan dan fasilitas air bersih lain ternyata masih bclum dimanfaatkan dengan baik, antara disebabkan oleh kurang efektifnya serta mahalnya beaya perawatan. Hal sersebut dapat pula diidentikkan dengan situasi yang terdapat di kota-kota lecil seperti Kutoarjo, Prembun dan Xutowinangun.

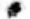

\section{METODE PENELITLAN}

Penelitian ini dilakukan di tiga kota kecil yang merupakan ibukota kecamatan. Satuan dacrah yang digunakan dalam penelitian ini adalah satuan wilayah administrasi ibukota kecamatankecamatan Kutowinangun, Prembun dan Kutoarjo. Dalam kaitan dengan penelitian ini dikumpulkan data yang berupa data fisik dan data kependudukan. Data fisik meliputi data geologi, tanah dan hidrologi, yang sebagian besar diperoleh dari hasil pengamatan di lapangan. Data kependudukan diperoleh di lapangan dengan wawancara dan dari registrasi statistik daerah di tiga kota kecamatan tersebut. Beberapa sampel air tanah telah diambil dari sumur gali di tiga kota tersebut. Analisis air dilakukan di Laboratorium Hidrologi dan Kualitas Air Fakultas Geografi UGM. Data sistem sanitasi lingkungan juga diamati langsung di lapangan.

Analisis terhadap data yang diperoleh dari pengamatan di lapangan serta analisis laboratorium dilakukan dengan cara analisis varians serta dengan analisis deskriptif kualitatif. Hasil analisis kualitas air diplotkan sesuai dengan titik pengambilannya untuk mendapatkan gambaran tentang agihan kualitas air menurut ruang serta kemungkinan faktor yang mempengaruhinya.

\section{HASIL PENELITIAN}

\section{Kondisi Umum Daerah Peneliti- an}

Kecamatan Kutowinangun dan Kecamatan Prembun merupakan bagian dari Kabupaten Kebumen, Jawa Tengah, sedang Kecamatan Kutoarjo merupakan bagian dari Kabupaten Purworejo, Propinsi Jawa Tengah. Kutowinangun terletak kita-kira $12 \mathrm{~km}$ di sebelah timur ibukota Kabupaten Kebumen, sedangkan Prembun terletak 


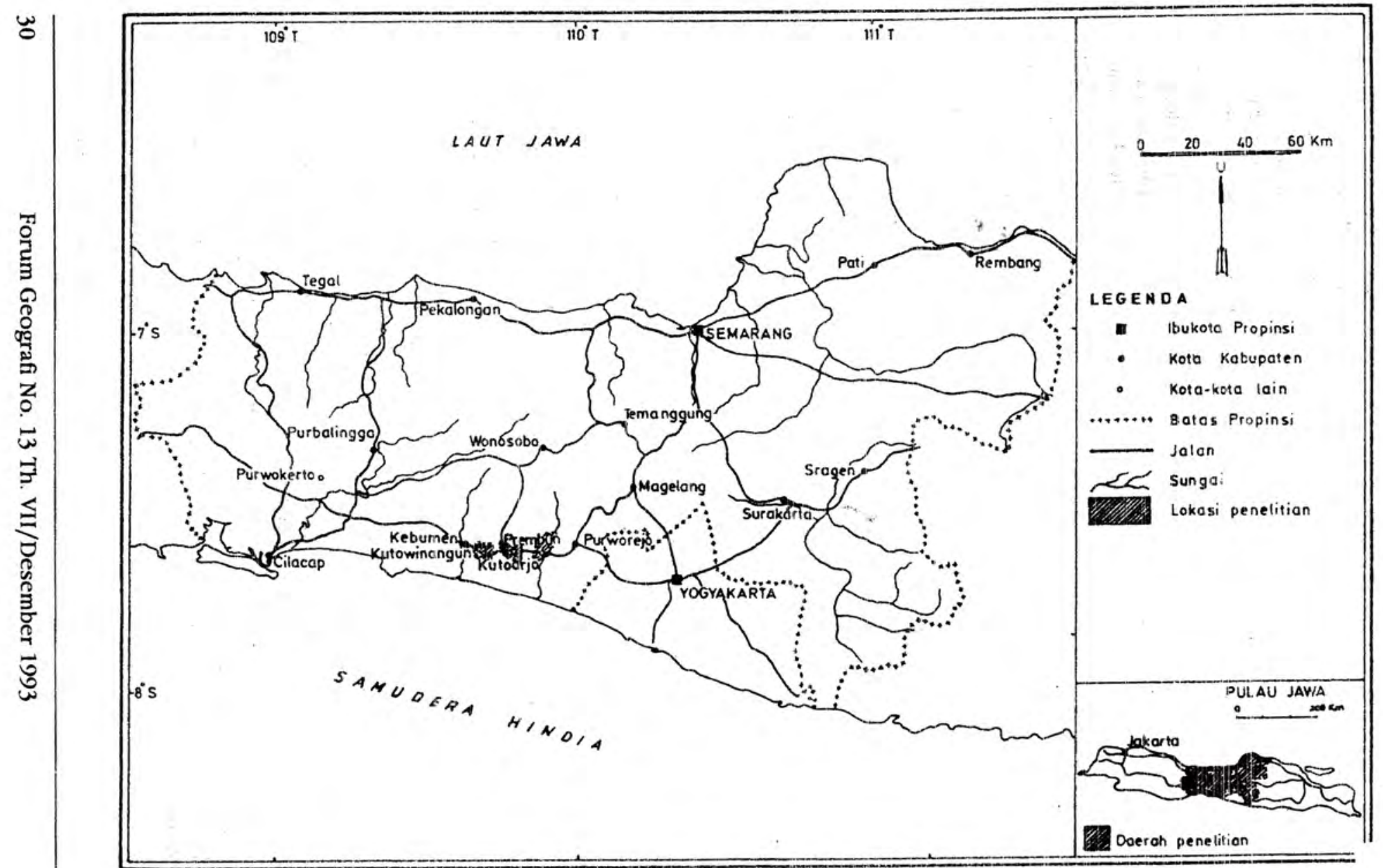

Gambar 1. Lokasi Penelitian 


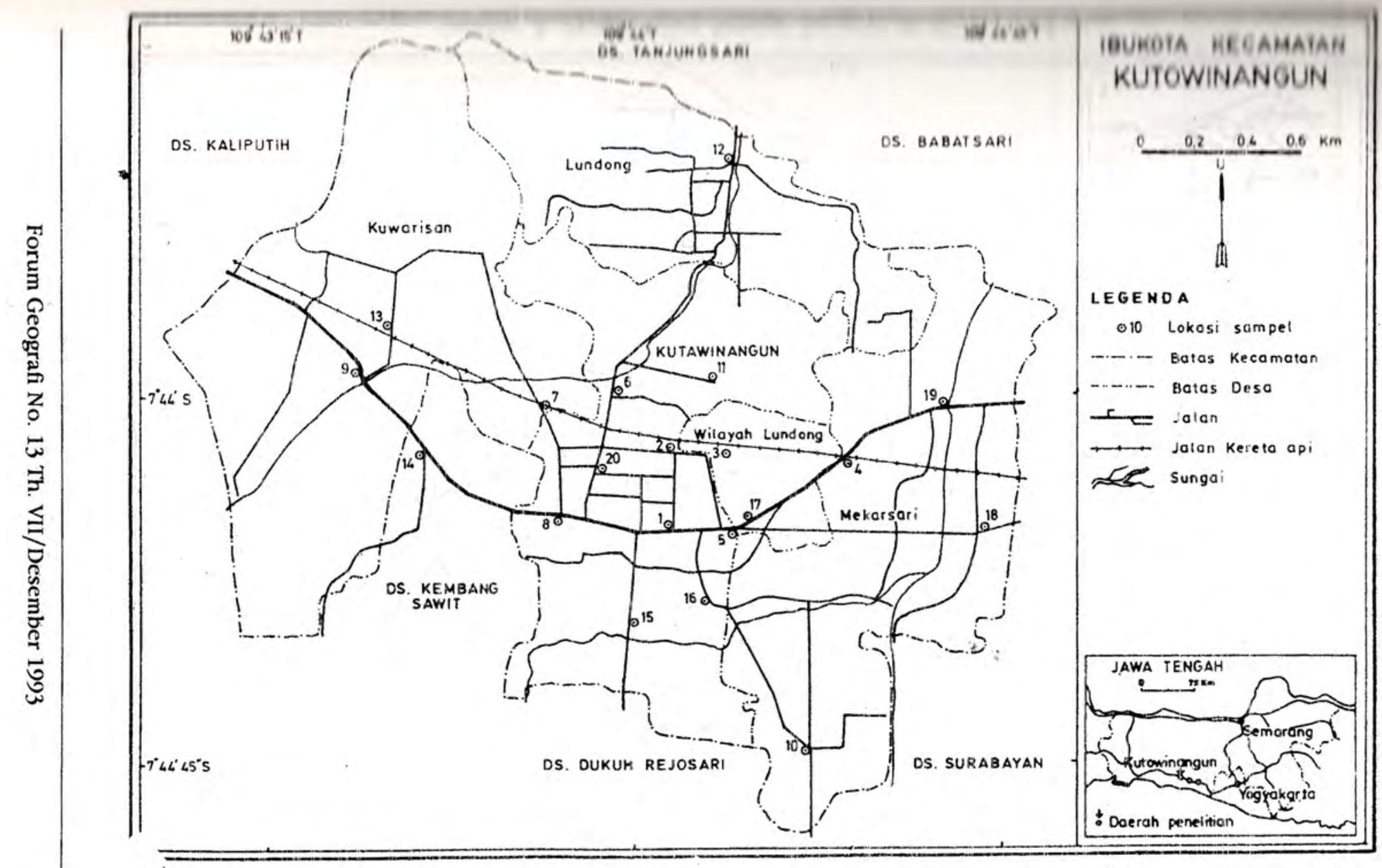

Gambar 2. Pengambilan Sampel Airtanah di Kota Kutowinangun 


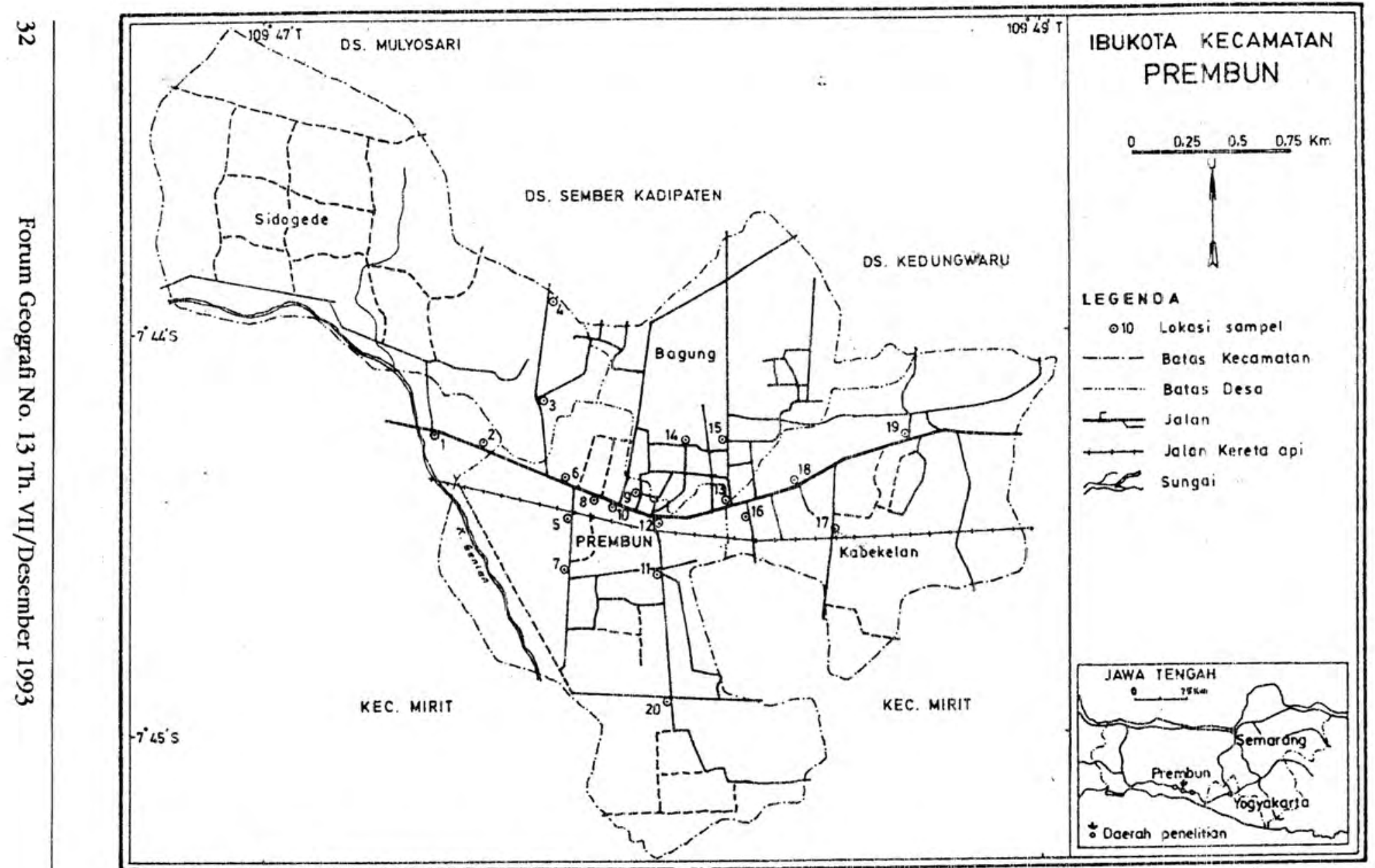

Gambar 3. Pengambilan Sampel Airtanah di Kota Prembun 


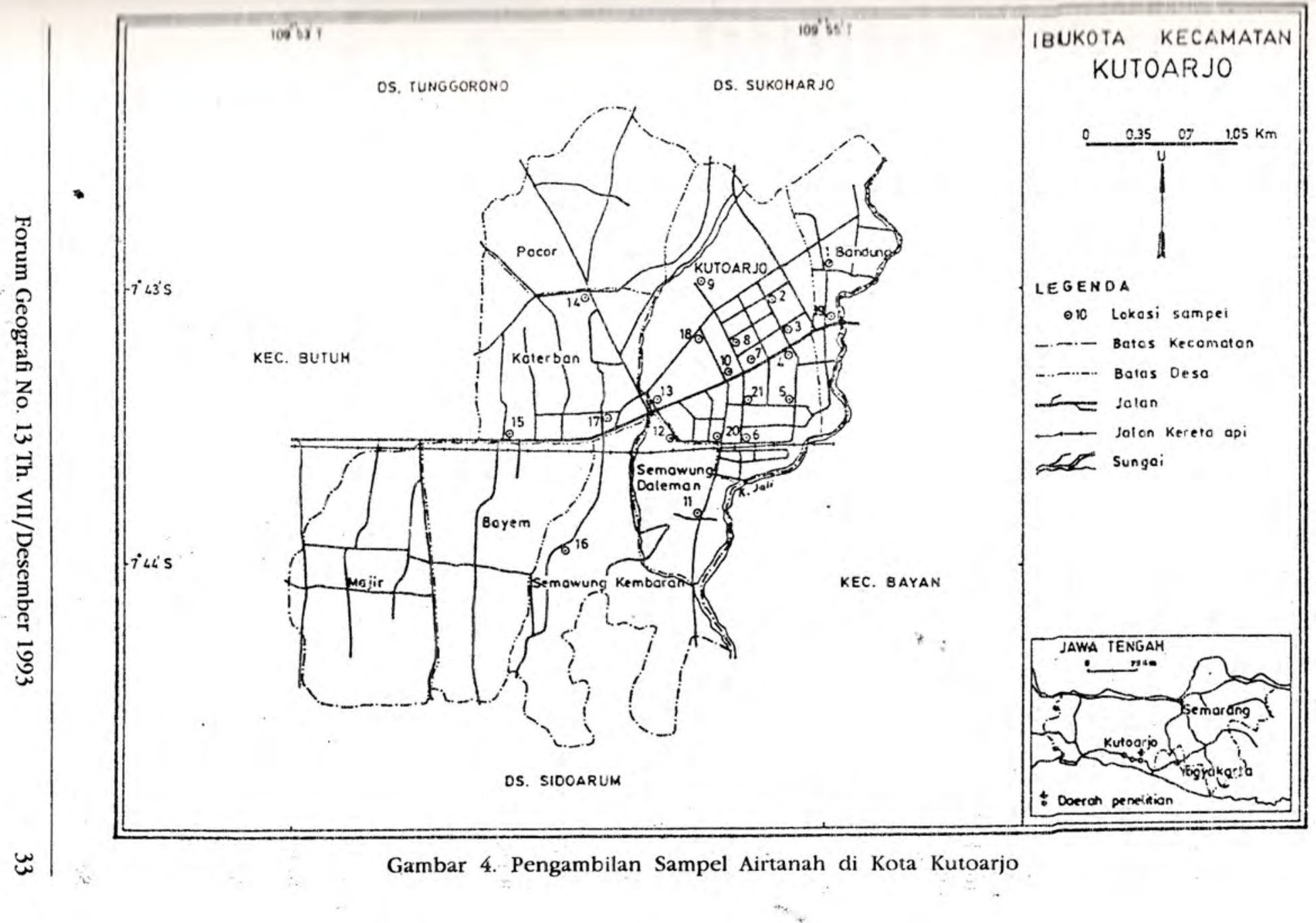


lebih ke timur lagi, yaitu kurang lebih $18 \mathrm{~km}$ dari Kebumen. Kutoarjo berjarak $31 \mathrm{~km}$ di scbelah timur Kebumen, atau kurang lebih $10 \mathrm{~km}$ ke arah barat dari Purworejo. Ketiga ibukota kecamatan yang dijadikan daerah penelitian ini dilalui oleh jalan aspal yang merupakan jalan negara yang menghubungkan kota-kota di Pulau Jawa bagian selatan (Gambar 1 hingga Gambar 4). Oleh karena itu kendaraan angkutan umum yang melalui jalur ini mempunyai frekuensi yang tinggi. Disamping itu, ketiga kota tersebut merupakan pusat kegiatan perdagangan daerah desa-desa di sekitarnya.

Topografi kota Kutowinangun dan Prembun dan sekitarnya datar, sehing. ga sekitar kota kecamatan Prembun dan Kutowinangun sering mengalami banjir. Kutoarjo mempunyai topografi yang landai sehingga di kota ini tidak terjadi genangan apabila musim hujan. Air tanah di kota-kota tersebut umumnya mempunyai kedalaman kurang dari $2 \mathrm{~m}$, sehingga diklasifikasikan sebagai air tanah yang sangat dangkal. Tanah di dacrah yang bersangkutan merupakan jenis Aluvial dengan tekstur lempung, schingga permcabilitasnya lambat.

Curah hujan di ketiga kota tersebut disajikan pada Tabel 1. Buian-bulan Mei-Oktober merupakan bulan-bulan dengan curah hujan yang rendah, sedangkan bulan Nopember-April merupakan bulan-bulan dengan curah hujan yang tinggi. Curah hujan sctahun di Kutowinangun, Prembun dan Kutoarjo masing-masing sebesar $2264 \mathrm{~mm}, 2150$ $\mathrm{mm}$ dan $2175 \mathrm{~mm}$.

Jumlah penduduk mempunyai hubungan erat dengan kebutuhan air serta limbah yang dihasilkannya. Jumlah penduduk di ibukota kecamatan Kutowinangun sebesar 12539 jiwa tersebar dalam 4 desa dengan wilayah seluas 495,01 ha. Kepadatan penduduk ratarata di wilayah ini sebesar $25 \mathrm{jiwa} / \mathrm{ha}$, dengan kisaran antara 18 hingga 42 jiwa/ha.

Tabel 1. Curah hujan di Kutowinangun, Prembun dan Kutoarjo (1950-1982)

\begin{tabular}{lccc}
\hline Bulan & \multicolumn{3}{c}{ Curah hujan $(\mathrm{mm})$} \\
\cline { 2 - 4 } & Kutowinangun & Prembun & Kutoarjo \\
\hline Januari & 341 & 329 & 344 \\
Fcbruari & 256 & 254 & 268 \\
Maret & 326 & 266 & 272 \\
April & 202 & 163 & 271 \\
Mei & 160 & 144 & 150 \\
Juni & 105 & 85 & 61 \\
Juli & 82 & 50 & 75 \\
Agustus & 56 & 52 & 36 \\
September & 44 & 38 & 49 \\
Oktober & 44 & 158 & 152 \\
Nopember & 306 & 314 & 277 \\
Desember & 341 & 297 & 320 \\
\hline Setahun & 2264 & 2150 & 217 \\
\hline
\end{tabular}


Daerah Kota Prembun mempunyai jumlah penduduk 18194 jiwa yang tersebar di 4 desa yang mempunyai luas wilayah 764,04 ha, schingga kepadatannya sebesar 24 jiwa/ha dengan kisaran antara 23,81 hingga 23,83 jiwa/ ha. lbukota kecamatan Kutoario mempunyai jumlah penduduk 30982 jiwa yang mendiami 8 desa seiuas 1124,6 ha, sehingga kepadatan penduduk di kota itu sebesar $28 \mathrm{jiwa} / \mathrm{ha}$, dengan kisaran antara 11 hingga 58 jiwa/ha. Rincian selengkapnya mengenai jumlah dan kepadatan penduduk di tiga ibukota kecamatan yang diteliti disajikan pada Tabel 2.
Jumlah sarana transportasi di tiga kota tersebut dapat memberikan gambaran konstribusinya pada pencemaran air di kota itu (Tabel 3). Mengingat sarana transportasi sederhana berupa kereta kuda (andong) masih banyak digunakan di tiga kota tersebut, kotoran kuda dengan berbagai cara walaupun tidak secara langsung mencemari air tanah di kota itu. Data sarana transpor. tasi yang diperoleh bukan merupakan yang berasal dari dalam kota itu, tetapi justru data yang diperolch dari scluruh kecamatan.

Tabel 2. Jumlah dan kepadatan penduduk Ibukota Kecamatan-kecamatan Kutowinangun, Prembun dan Kutoarjo

\begin{tabular}{|c|c|c|c|c|c|}
\hline Kecamatan & Desa & $\begin{array}{l}\text { Luas } \\
\text { (ha) }\end{array}$ & $\begin{array}{l}\text { Jml. Pddk } \\
\text { (jiwa) }\end{array}$ & $\begin{array}{l}\text { Kpdt.pddk } \\
\text { (jiwa/ha) }\end{array}$ & Klas \\
\hline \multirow[t]{5}{*}{ Kutowinangun } & Kutowinangun & 108,00 & 4506 & 41,72 & $\mathrm{D}$ \\
\hline & Kuwarisan & 157,85 & 3362 & 21,45 & B \\
\hline & Lundong & 101,11 & 1826 & 18,06 & A \\
\hline & Mekarsari & 128,25 & 2825 & 22,03 & B \\
\hline & & 495,01 & 12539 & & \\
\hline \multirow[t]{5}{*}{ Prembun } & Prembun & 185,50 & 4417 & 23,81 & B \\
\hline & Bagung & 130,36 & 3107 & 23,83 & B \\
\hline & Kabekelan & 155,02 & 3691 & 23,81 & B \\
\hline & Sidogede & 293,15 & 6979 & 23,81 & \\
\hline & & 764,03 & 18192 & & \\
\hline \multirow[t]{9}{*}{ Kutoarjo } & Kutoarjo & 237,84 & 13800 & 58,02 & \\
\hline & Bandung & 46,90 & 1999 & 42,62 & D \\
\hline & Kembaran & 116,80 & 1800 & 15,41 & A \\
\hline & Daleman & 117,84 & 3722 & 31,59 & C \\
\hline & Bayem & 142,21 & 2234 & 15,71 & A \\
\hline & Majir & 162,22 & 1861 & 11,47 & A \\
\hline & Katerban & 141,65 & 3762 & 26,56 & B \\
\hline & Pacor & 159,14 & 1804 & 11,34 & A \\
\hline & & 1124,60 & 30982 & 28 & \\
\hline
\end{tabular}


Tabel 3. Jenis dan Jumlah Sarana Transportasi di Kecamatan Kutowinangun, Prembun dan Kutoarjo

\begin{tabular}{lccc}
\hline & \multicolumn{3}{c}{ Jumlah di masing-masing Kecamatan } \\
\cline { 2 - 4 } Jenis Kendaraan & Kutowinangun & Prembun & Kutoarjo \\
\hline Sepeda & 5661 & 1947 & 7687 \\
Dokar/delman & 53 & 43 & 29 \\
Gerobak & 47 & 12 & 117 \\
Becak & 45 & 52 & 303 \\
Sepeda motor & 543 & 278 & 106 \\
Mikrolet & 0 & 0 & 147 \\
Mobil (Dinas/pribadi) & 24 & 29 & 31 \\
Truck & 19 & 19 & 28 \\
Bus & 0 & 0 & 26 \\
\hline
\end{tabular}

\section{Kualitas Air Tanah}

Parameter kualitas air yang diteliti adalah daya hantar listrik (DHL), klorida $(\mathrm{Cl})$, Nitrit $\left(\mathrm{NO}_{2}\right)$, Nitrat $(\mathrm{NO} 3)$, Sulfat $\left(\mathrm{SO}_{4}\right), \mathrm{COD}, \mathrm{BOD}$ dan bakteri coliform. Contoh air tanah diambil dari sumur gali yang digunakan sehari-hari untuk keperluan masak, minum dan cuci. Jumlah contoh air yang diambil sebanyak 21 buah di daerah Kutowinangun dan Kutoarjo, sedang di Prembun diambil sebanyak 20 buah contoh. Lokasi pengambilan contoh air tanah diberikan dalam Gambar 1 hingga Gambar 3. Hasil analisis air tersebut disajikan pada Tabel L-1 hingga Tabel L.3. Berdasarkan hasil analisis air tanah di tiga kota kecamatan tersebut dapat dijelaskan sebagai berikut.

Tanda-tanda adanya pencemaran air tanah dapat diketahui dari kandungan parameter $\mathrm{NO}_{3}$, COD dan Bakteri bentuk coli. Air tanah di ketiga telah mengalami pencemaran dengan tingginya angka bakteri coli. Bakteri coli di tiga kota kecamatan tersebut telah mencapai lebih dari $2400 \mathrm{MPN} / 100$ ml. Kutoarjo kadar $\mathrm{NO}_{3}$ kebanyakan sudah melampaui $5 \mathrm{mg} / \mathrm{L}$ ( $52 \%$ dari jumfah sampel), di Kutowinangun 28\% dan di Prembun sekitar 25\% sampel. Berdasarkan atas kadar $\mathrm{NO}_{3}$ dan $\mathrm{COD}$, dibandingkan dengan baku mutu air, air tanah didaerah penelitian masih memenuhi air Golongan B. Air tanah dengan kadar $\mathrm{NO}_{3}$ yang tinggi pada umumnya terdapat di pusat kota. Sum. ber $\mathrm{N}$ terdapat di udara, namun demikian unsur $\mathrm{N}$ dalam air tanah dapat dimungkinkan berasal dari unsur $\mathrm{N}$ yang terdapat dalam limbah organik padat maupun pupuk. Mengingat ketiga ibukota kecamatan tersebut merupakan kota administrasi dan pusat kegiatan penduduk, besar kemungkinan $\mathrm{N}$ dalam air tanah ini berasal dari limbah domestik. Hal ini didukung dengan fakta bahwa kadar $\mathrm{NO}_{3}$ yang tinggi terdapat pada air tanah yang terdapat di pusat kota yang padat penduduk.

Sampel yang mempunyai COD tinggi melampaui ambang batas baku mutu air golongan B (lebih dari $10 \mathrm{mg} / \mathrm{l}$ ) adalah sebagai berikut. Di Kutowinangun, 43\% dari jumlah sampel mempunyai angka BOD lebih dari $10 \mathrm{mg} / \mathrm{l}$, 
di Prembun 20\%, tetapi di Kutoarjo tidak terdapat sampel yang mempunyai COD lebih dari $10 \mathrm{mg} / \mathrm{l}$. Di Kutowinangun air tanah tcrletak sangat dangkal dan sering terjadi genangan di kota itu. Di tiga ibukota kecamatan kadar parameter yang teramati kadang berbeda, tetapi kadang pula menunjukkan tidak ada perbedaan. Hal ini terlihat dari uji statistik menggunakan uji $\mathrm{F}$ yang dilakukan untuk melihat perbedaan kadar parameter di ketiga kota tersebut (lihat Tabel L-4). Hasil uji statistik menghasilkan hal-hal sebagai berikut.

Parameter DHL, $\mathrm{NO}_{3}$ dan bakteri coli menunjukkan tidak ada perbedaan yang signifikan di ketiga kota tersebut, sedangkan klorida $(\mathrm{Cl})$ Nitrit $\left(\mathrm{NO}_{2}\right)$, COD dan BOD menunjukkan perbedaan yang signifikan.

Parameter klorida (Cl) di Prembun dan Kutowinangun menunjukkan perbedaan yang signifikan,s edang unsur yang sama di dalam air tanah di Prembun dan Kutoarjo tidak menunjukkan perbedaan yang signifikan. Airtanah di Kutowinangun menunjukkan kadar $\mathrm{Cl}$ yang lebih tinggi dibandingkan dengan kadarnya di dalam air tanah di Kutoarjo maupun di Prembun. Di Kutowinangun airtanah mempunyai kadar $\mathrm{Cl}$ rata-rata sebesar $50,31 \mathrm{mg} / \mathrm{l}$, di Prembun sebesar $33,06 \mathrm{mg} / 1$ dan Kutoarjo mempunyai kadar $\mathrm{Cl}$ rata-rata sebesar $44,10 \mathrm{mg} / \mathrm{l}$. Walaupun demikian kadar $\mathrm{Cl}$ di ketiga kota tersebut masih dibawah batas maksimum yang diperbolehkan $(600 \mathrm{mg} / \mathrm{l})$.

Parameter $\mathrm{NO}_{2}$ airtanah di Kutowinangun mempunyai kadar yang berbeda dari kadarnya di dalam airtanah di Prembun maupun Kutoarjo, sedang di Prembun dan Kutoarjo air tanah mempunyai kadar $\mathrm{NO}_{2}$ yang sama. Ada kecenderungan bahwa di daerah pusat kota air tanah mempunyai kadar $\mathrm{NO}_{2}$ yang lebih tinggi daripada dacrah sekitarnya. Ilal ini antara lain karena lim. bah yang dihasilkan di pusat kota lebih banyak daripada sckitarnya (pinggiran kota), sedang sistem pembuangan limbah tersebut tidak dilakukan dengan baik.

COD dalam air tanah di Kutowinangun tidak berbeda dengan air tanah di Prembun. Namun air tanah di Kutowinangun dan di Prembun berbeda dengan air tanah di Kutoarjo. Rata-rata COD dalam air tanah di Kutowinangun, Prembun dan Kutoarjo masing. masing adalah $10,13 \mathrm{mg} / 1,8,62 \mathrm{mg} / 1$ dan $1,83 \mathrm{mg} / \mathrm{l}$. BOD dalam air tanah di Kutowinangun dan Prembun menunjukkan perbedaan yang berarti, demikian juga antara air tanah di Kuto. winangun dan Kutoarjo. Namun antara air tanah di Prembun dan di Kutoarjo tidak menunjukkan kadar BOD yang cukup berarti. Masing-masing kadar BOD untuk air tanah diKutowinangun, Prembun dan Kutoarjo adalah 1,7.4 $\mathrm{mg} / 1,1,2 \mathrm{mg} / 1$ dan $0,68 \mathrm{mg} / 1$. Dari hasil analisis COD dan BOD di ketiga kota kecamatan antara bahwa BOD dan COD dalam air tanah di Kutoarjo menunjukkan nilai yang paling rendah di antara ketiha kota tersebut, jadi ditinjau dari parameter ini tingkat pencemaran air tanah di Kutoarjo lebih rendah daripada di Kutowinangun dan Prembun.

\section{Persepsi Masyarakat}

Pendidikan atau pengetahuan seseorang akan berpengaruh terhadap penilaian pada berbagai hal, termasuk pa. da sanitasi dan kesehatan lingkungan. Dari 72 orang responden yang diwawancarai terungkap bahwa sebagian besar tidak mengetahui istilah-istilah 
yang berkaitan dengan pencemaran lingkungan. Beberapa istilah yang terkait dengan pencemaran lingkungan umumnya diperoleh dari penyuluhan. penyuluhan yang dilakukan oleh Pemerintah setempat. Penduduk yang tidak mengetahui istilah yang berkaitan dengan pencemaran lingkungan umumnya mereka yang hanya mempunyai pendidikan dasar. Namun demikian bukan berarti bahwa penduduk dengan pendidikan menengah mengerti betul akan istilah pencemaran dan sanitasi lingkungan. Banyak di antara mereka hanya mengerti secara setengah-setengah saja.

Dalam kaitannya dengan pencemaran air yang dilontarkan kepada responden, sebagian besar mereka menjawab bahwa air yang digunakan masih baik, dalam arti tidak mengganggu kesehatan. Hasil uji laboratorium menunjukkan bahwa air tanah di daerah penelitian sudah menurun kualitasnya, walaupun belum sampai ke tingkat yang membahayakan. Menurunnya kualitas air di daerah penelitian belum terasa olch penduduk. Pengamatan di lapangan menunjukkan pula bahwa air yang digunakan scbagian menunjukkan bau yang kurang enak serta kekeruhan yang tinggi. Penduduk sudah terbiasa dengan keadaan yang demikian, sehingga tidak dirasakan mengganggu kesehatan maupun indera. Segi estetika (rasa dan bau) nampaknya tidak atau belum banyak diperhatikan.

\section{Sanitasi Lingkungan}

Dari pengamatan yang dilakukan di lapangan maupun di laboratorium, diantara tiga kota kecamatan yang diteliti, Kutoarjo memiliki kualitas air yang terbaik di antara tiga kota ter- scbut. IIal tersebut dapat diduga, selain discbabkan olch keadaan tanah yang lebih baik di kota ini, juga discbabkan olch sistem pembuangan limbah yang lebih teratur. Di Kutowinangun saluran pembuangan limbah masih kurang baik, bahkan banyak penduduk yang membuang limbah di halaman atau di tempat-tempat terbuka, sehingga menyebabkan limbah tersebut dapat terbawa masuk ke dalam air tanah. Saluran pembuangan limbah banyak yang masih merupakan saluran terbuka tanpa disemen. Hal ini menyebabkan kemungkinan terjadinya peresapan air ke dalam air tanah.

Di Kecamatan Prembun dan Kutoarjo sistem pembuangan limbah dilakukan dengan cara membuang melalui saluran pembuang, walaupun sebenarnya saluran ini juga diperuntukkan sebagai saluran drainase air hujan. Saluran induk pembuang limbah sudah disemen. Hal yang teramati di lapangan menunjukkan bahwa banyak limbah dari tempat umum (pasar, terminal dan lain sebagainya) tercecer di jalan raya, dan mungkin ini merupakan sumber pencemar bagi air tanah. Lebih-lebih kotoran kuda juga banyak didapatkan di jalan- jalan raya yang tidak terbersihkan dengan baik (lihat Tabel 3).

\section{KESIMPULAN}

1. Kualitas air tanah di tiga kota Kecamatan, yaitu Kutowinangun, Prembun dan Kutoarjo secara keseluruhan terlihat sudah menunjukkan gejala penurunan, walaupun masih belum melampaui ambang batas maksimum baku mutu Golongan B. Penurunan tersebut terlihat dari angka bakteri coli yang tinggi serta kadar $\mathrm{NO}_{2}, \mathrm{NO}_{3}, \mathrm{Cl}$ 
serta COD dan BOD yang relatif tinggi pula; kecuali COD dan $\mathrm{BOD}$ dalam air tanah di Kutoarjo yang masih rendah.

2. Di antara tiga kota kecamatan tersebut, Kutoarjo memiliki kualitas airtanah yang tcrbaik; hal ini disebabkan karena sistem sanitasi lingkungan di kota tersebut terbaik di antara ketiga kota tersebut. Kutowinangun dan Prembun lebih sering tergenang air pada musim hujan daripada Kutoarjo, sehingga drainase kedua kota tersebut lebih jelek dibandingkan Kutoarjo. Kemungkinan airtanah tercemar lebih besar, lebih-lebih apabila kedalaman airtanah ini diperhatikan, kedua kota tersebut mempunyai letak airtanah yang lcbih dangkal daripada Kutoarjo.

3. Pengetahuan masyarakat serta kepeduliannya terhadap keschatan lingkungan masih harus ditingkatkan. Hal ini terungkap dari persepsi masyarakat terhadap lingkungan yang terkait pula dengan masalah kualitas airtanah sebagai sumber air minumnya. Pendidikan sangat mempengaruhi persepsinya terhadap kesehatan lingkungan, termasuk persepsinya kepada pencemaran air dan kualitas airtanah. Persepsi yang rendah dijumpai pada sebagian penduduk yang berpendidikan lebih rendah daripada SITP.

\section{DAFTAR PUSTAKA}

Seyhan, E., 1977. Application of Statistical Method to Hydrology. Institute of Earth Sciences, Free University, Amsterdam.

Sudarmadji, 1991. Agihan Geografi Sifat Kimiawi Airtanah Bebas di Kotamadya Yogyakarta. Disertasi Doktor, Universitas Gadjah Mada, Yogyakarta.

Sudarmadji dan Suyono, 1994. Pola Penggunaan Air dan Pembuangan Limbah di Kompleks Perumahan Banteng Baru dan Pengaruhnya terhadap Hidrologi Lingkungan Sekitar. Fakultas Geografi Lembaga Penelitian Universitas Gadjah Mada, Yogyakarta.

Sudarmadji dan Darmakusuma Darmanto. 1989. Evaiuasi terhadap Pemanfaatan Sarana Air Bersih di Dusun Banteng, Sleman, DrY. Fakultas Geografi UGM, Yogyakarta.

Suyono, Sudarmadji dan Slamet Suprayogi, 1983. Pengaruh Sistem Sanitasi Lingkungan terhadap Kualitas Air di Tiga Ibukota Kecamatan (Kutoarjo, Prembun dan Kutowinangun) daerah Aluvial Pantai Selatan Jawa Tengah. Fakultas Gcografi UGM, Yogyakarta.

Hem, J.D. 1970. Study and Interpretation of the Chemical Characteristics of Natural Water. United States Geological Survey Water Supply Paper. No. 1473, US Gov. Printing Office, Washington.

Tood, D.K., 1980. Groundwater Hydrology. John Wilcy, Washington.

Yamamoto, S. dan Hids, N., 1974. A Preleminary Study on Groundwater Pollution in the Western Sub Urban of Tokyo Metropolitan. Science Report of Tokyo Kyeku Daigahu, March. 
Tabel L-1. Hasil Analisis Kualitas Airtanuh di Kutowirangun

\begin{tabular}{|c|c|c|c|c|c|c|c|c|c|c|}
\hline No & No. Lab. & $\begin{array}{c}\text { Temp } \\
\alpha C\end{array}$ & $\mathrm{EH}$ & $\begin{array}{c}\text { DHL } \\
\text { umbo/cm }\end{array}$ & $\begin{array}{l}\mathrm{Cl} \\
\mathrm{m} \mathrm{g} / \mathrm{I}\end{array}$ & $\begin{array}{l}\mathrm{NO}_{2} \\
\mathrm{mLg} / 1\end{array}$ & $\begin{array}{l}\text { NO3 } \\
\mathrm{mg} / 1\end{array}$ & $\begin{array}{l}\mathrm{SO}^{4} \\
\mathrm{mg} / 1\end{array}$ & $\begin{array}{l}\text { COD } \\
\mathrm{mg} / 1\end{array}$ & $\begin{array}{l}\mathrm{BOD} \\
\mathrm{mg} / \mathrm{l}\end{array}$ \\
\hline 1 & $76 / \mathrm{LH} / 1 \mathrm{BK}$ & 27,3 & 7,3 & 1083 & 175 & 0,006 & 1,0 & 104,0 & $B, 43$ & 0,92 \\
\hline 2 & $77 / \mathrm{LH} / 2 \mathrm{aK}$ & 28,0 & 8,0 & 970 & 105 & 0,073 & 17,0 & 22,0 & 18,06 & 0,24 \\
\hline 3 & $78 / \mathrm{LH} / 3 \mathrm{bK}$ & 27,5 & 7,5 & 697 & 48,8 & 0,023 & 1,0 & 2,0 & 10,23 & 8. ? \\
\hline 4 & $79 / \mathrm{LH} / 4 \mathrm{k}$ & 27,1 & 7,5 & 815 & 48,8 & 0,004 & 5,0 & 12,5 & 11.13 & 2,93 \\
\hline 5 & $80 / \mathrm{LH} / 4 \mathrm{bK}$ & 28,6 & 7,0 & 681 & 44,9 & 0,064 & 17,0 & 13,6 & 12,34 & 5,50 \\
\hline 6 & $81 / \mathrm{LH} / 5 \mathrm{aK}$ & - & - & - & 83,9 & 0,004 & 4,0 & 17,4 & 5,42 & 3,30 \\
\hline 7 & 82/LH/6K & 27,9 & 7,3 & 481 & 19,5 & 0,009 & 0,0 & 11,5 & 9,03 & 0,70 \\
\hline 8 & $83 / \mathrm{LH} / 7 \mathrm{~K}$ & 26,9 & 7,2 & 539 & 39,0 & 0,057 & 6,0 & 18,9 & 13,24 & 1,20 \\
\hline 9 & 64/LH/7aK & 28,7 & 7,1 & 443 & 19,5 & 0,004 & 2,0 & 30,5 & B. 62 & 1,10 \\
\hline 10 & $85 / \mathrm{LH} / 8 \mathrm{~K}$ & - & - & 431 & 27,3 & 0,004 & 1,0 & 24,1 & 7,22 & 1,20 \\
\hline 11 & $86 / \mathrm{LH} / 9 \mathrm{~K}$ & 27,2 & $\cdot 7,3$ & 280 & 13,7 & 0,006 & 1,0 & 13,6 & 3,91 & 0,40 \\
\hline 12 & $87 / \mathrm{LH} / 10 \mathrm{~K}$ & 26,9 & $=7,3$ & 571 & 62,4 & 0,004 & 1,0 & 30,5 & 7,22 & 1,90 \\
\hline 13 & $83 / \mathrm{LH} / 11 \mathrm{~K}$ & 27,7 & 7,1 & 492 & 31,2 & 0,004 & 1,0 & 15,7 & 3,43 & 1,30 \\
\hline 14 & $89 / \mathrm{LH} / 12 \mathrm{~K}$ & 26,2 & 7,3 & 822 & 50,7 & 0.009 & 1,0 & 24,1 & 10,83 & 1,50 \\
\hline 15 & $90 / \mathrm{LH} / 13 \mathrm{~K}$ & 26,8 & - & 710 & 64,4 & 13,034 & 5,5 & 14,2 & 10,83 & 2,90 \\
\hline 16 & 91/LH/14K & 27,7 & 3,0 & 310 & 13,7 & 0,023 & 2,3 & 9,4 & 8,73 & 0,10 \\
\hline 17 & $92 / \mathrm{LH} / 15 \mathrm{~K}$ & 26,6 & 7,3 & 6:iij & 56,6 & 13,031 & 4,5 & 13,9 & 14,44 & 0,20 \\
\hline 18 & $93 / \mathrm{LH} / 16 \mathrm{~K}$ & 27,2 & 7,3 & 712 & 60,5 & $0,00 k_{i}$ & 2,3 & 14,6 & 4,21 & 1,50 \\
\hline 19 & 94/LH/18K & 27,2 & 7,4 & 525 & 21,5 & 0,004 & 0,0 & 9,4 & 9,95 & $0,2 / 5$ \\
\hline 20 & 95/LH/19K & 27,5 & 6,9 & 412 & 19,5 & 0,018 & 6,6 & 26,2 & 22,57 & 1,50 \\
\hline 21 & $96 / \mathrm{LH} / 20 \mathrm{~K}$ & 27,6 & 7,4 & 682 & 50,7 & 0,020 & 4,5 & 12,5 & 9,92 & 1,42 \\
\hline
\end{tabular}

Tabel L-2. Hasil Analisis Kualitas Airtanah di Prembun

\begin{tabular}{|c|c|c|c|c|c|c|c|c|c|c|}
\hline No & No. Lab. & Temp & $\mathrm{pH}$ & $\begin{array}{c}\text { DHL } \\
\text { umho/cm }\end{array}$ & $\begin{array}{l}\mathrm{Cl} \\
\mathrm{mg} / \mathrm{l}\end{array}$ & $\begin{array}{l}\mathrm{NO2} \\
\mathrm{me} / 1\end{array}$ & $\begin{array}{r}\mathrm{NOS} \\
\mathrm{m} \operatorname{sg} / 1\end{array}$ & $\begin{array}{l}\mathrm{SO} 4 \\
\mathrm{nug} / 1\end{array}$ & $\begin{array}{l}\mathrm{COD} \\
\mathrm{nig} / 1\end{array}$ & $\begin{array}{l}\mathrm{POD} \\
\mathrm{me} / 1\end{array}$ \\
\hline 1 & $97 / \mathrm{LH} / 1 \mathrm{Pr}$ & 26,9 & 7,2 & 530 & 11,7 & 0,000 & 0,6 & 13,2 & 8,42 & 1,75 \\
\hline 2 & $98 / \mathrm{LH} / 2 \mathrm{Pr}$ & 25,5 & 7,4 & 456 & 11.7 & $?, 000$ & 0.6 & 13,9 & 3,61 & 0,90 \\
\hline 3 & $99 / \mathrm{LH} / 3 \mathrm{Pr}$ & $26, F$ & 7,2 & 481 & 21,5 & 0,009 & 2,3 & 30,5 & 6,62 & 1,10 \\
\hline 4 & $100 / \mathrm{LH} / 4 \mathrm{Pr}$ & 25,9 & 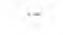 & 563 & 19,5 & $0,00 \mathrm{i}$ & 18,5 & 23,3 & 6,02 & 1,20 \\
\hline 5 & $101 / \mathrm{LH} / \mathrm{SPr}$ & 26,9 & & 760 & 40,3 & 0.004 & 3,4 & 45,2 & 5,03 & 0,90 \\
\hline 6 & $102 / \mathrm{LH} / \mathrm{GEr}$ & 27,4 & & 503 & $\mathfrak{G}_{3}, 5$ & $0,004 k$ & 3,4 & 30,5 & 9,03 & 0,50 \\
\hline 7 & $103 / \mathrm{LH} / 7 \mathrm{Er}$ & 20,7 & & $42 \%$ & 21,2 & i). fijtis & $0, b$ & 22,0 & 30,09 & 0,20 \\
\hline 8 & $104 / \mathrm{LH} / 3 \mathrm{Pr}$ & 27,1 & & 588 & 13,5 & ij, but & 0,6 & 3,3 & 4,25 & 1,70 \\
\hline 9 & $105 / \mathrm{LH} / \mathrm{9Pr}$ & 28.2 & & 742 & 48.8 & 0,027 & 5,5 & 19,5 & 6,99 & 3,50 \\
\hline 10 & $106 / \mathrm{LH} / 10 \mathrm{Pr}$ & 27,0 & & 630 & 25,4 & U, 005 & 7,7 & 24.2 & $5, \% 7$ & 0,10 \\
\hline 11 & $107 / \mathrm{LH} / 11 \mathrm{Pr}$ & 26,0 & & 470 & $2 t, 4$ & 0.004 & 4,5 & $24, j$ & 6,38 & 1,30 \\
\hline 12 & $108 / \mathrm{LH} / 12 \mathrm{Pr}$ & 27,3 & & .927 & 76,1 & 0.053 & 2,3 & 30,5 & 14,23 & 1,10 \\
\hline 13 & $109 / \mathrm{LH} / 13 \mathrm{PL}$ & 26,8 & & $6: 3: 3$ & 29,3 & i), icti & 2,3 & $3 ;, 2$ & 4,55 & 0,30 \\
\hline 14 & $110 / \mathrm{LH} / 14 \mathrm{H}^{\prime} \mathrm{r}$ & 27,3 & & 351 & 15.6 & 15.0134 & 2,3 & $2 \%, 0$ & $1 ; 2,43$ & $2 ., 60$ \\
\hline 15 & $111 / \mathrm{LH} / 15 \mathrm{Pr}$ & & & 638 & 37,1 & 1), OBC & $0,6^{2}$ & 24,1 & 2,73 & 1,30 \\
\hline 16 & $112 / \mathrm{LH} / 16 \mathrm{Pr}$ & 26.9 & & 654 & $52, \%$ & U, 0.23 & 12,0 & 13,0 & 5,16 & 1,00 \\
\hline 17 & $113 / \mathrm{LH} / 17 \mathrm{Pr}$ & 25,5 & & 831 & 79,9 & 0,004 & 4,5 & 22,0 & 10,94 & 0,50 \\
\hline 18 & $114 / \mathrm{LH} / 18 \mathrm{Pr}$ & 28.0 & & 716 & 40,9 & $\because, 000$ & 5,5 & 11,1 & 5,16 & 1,00 \\
\hline 19 & $115 / \mathrm{LH} / 19 \mathrm{Pr}$ & 26,5 & & 712 & 54,6 & 0,004 & 2,3 & 11,1 & 12,15 & 2,10 \\
\hline 20 & $116 / \mathrm{LH} / 20 \mathrm{Pr}$ & 26,5 & & 426 & 11.7 & 3,056 & 0,6 & 11.1 & 6,63 & 0,90 \\
\hline
\end{tabular}


Tabe:1 1. 3. Hasil Arualissis Kual itus Airturnah di Kutour.jo

\begin{tabular}{|c|c|c|c|c|c|c|c|c|c|c|}
\hline Bo & No. Lab. & $\begin{array}{c}\text { Temp } \\
\text { c }\end{array}$ & $\mathrm{FH}^{\mathrm{H}}$ & $\begin{array}{l}\text { DHL } \\
\mathrm{o} / \mathrm{cm}\end{array}$ & $\begin{array}{l}\mathrm{C} 1 \\
\mathrm{mg} / 1\end{array}$ & $\begin{array}{l}\mathrm{NO2} \\
\mathrm{mL} / 1\end{array}$ & $\begin{array}{r}\mathrm{NO3} \\
\mathrm{mg} / 1\end{array}$ & $\begin{array}{l}\mathrm{SO} 4 \\
\mathrm{mg} / 1\end{array}$ & $\begin{array}{l}\text { COD } \\
\mathrm{mg} / 1\end{array}$ & $\begin{array}{l}\mathrm{BOD} \\
\text { मूह / } 1\end{array}$ \\
\hline 1 & 135,1 & 27,0 & 7,4 & 370 & 19, & 005 & 22,5 & $1 y$ & 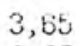 & 1 \\
\hline 2 & $131 / 20$ & & 7,0 & 375 & 21, &, 008 & 0,0 & 1 & &, 0 \\
\hline 3 & $138 / 3-\mathrm{KJ}$ & 28,6 & 7,2 & 619 & 58,5 &, 005 & 22,4 & 22,0 &, 68 & 20 \\
\hline 4 & $139 / 4 a-K J$ & 27,8 & 7,3 & 564 & 39,0 &, 005 & 0,0 & 17,8 & 8 &, 30 \\
\hline 5 & $140 / 5-\mathrm{KJ}$ & 27,4 & 6,5 & 375 & 48,8 &, 005 & 0,0 & 16,7 & 3,34 &, 50 \\
\hline 6 & $141 / 6 a-K J$ & 27,9 & 7,2 & 777 & $1 \cup 7,0$ & 0,030 & 36,0 & 36,8 & 1,56 & 0,40 \\
\hline 7 & $142 / 7 \mathrm{c}-\mathrm{KJ}$ & 28,4 & 7,2 & 484 & 39,0 &, 021 & 0,4 & 28,3 &, 16 & .30 \\
\hline 8 & $143 / 8-\mathrm{KJ}$ & 27,5 & 7,2 & 349 & 19,5 & 0,043 & 0,4 & 17,8 & 2,45 &, 20 \\
\hline 9 & $144 / 9 \mathrm{~b}-\mathrm{KJ}$ & 28,0 & 7,2 & 565 & 46,8 & 0,005 & 22,4 & 24,1 &, 32 &, 10 \\
\hline 10 & $145 / 10 \cdots k$ & 25,2 & 7,5 & 525 & 31,2 & 0,005 & $\because 2,4$ & 17,8 & 2,13 &, 30 \\
\hline 11 & $146 / 11 \mathrm{~b}-\mathrm{KJ}$ & 28,1 & 7,5 & 457 & 31,2 & 0,1 & 0,4 & 15,7 & 32. & 0,08 \\
\hline 12 & $147 / 120$ & 27,4 & 6,7 & 52.8 & 33,2 & 08 & 11,0 & 34 & 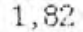 &, 10 \\
\hline 13 & $148 / 13-$ & 28,0 & 7,0 & 358 & 117,0 & 1 & 10,3 & $+58,7$ & $\$, 47$ & 10 \\
\hline 14 & $149 / 1$ & 26,1 & 7,3 & 452 & 29,0 & 5 & 0,0 & 1 & 4 &, 60 \\
\hline 15 & $150 / 1$ & 27 & 6,2 & 283 & 11,7 & 5 & 0,0 & 18 & 4 &, 10 \\
\hline 16 & 151, & 27,6 & 6,3 & 983 & 39,9 & & 0,39 & 41,0 & 3 &., 30 \\
\hline 17 & $152 /$ & 27,6 & 7,5 & 346 & 19,5 & 13 & 0,0 & 18,9 & 3 & 10 \\
\hline 18 & $153 /$ & 28,6 & 7,0 & 313 & 37,6 & 11 & 36,0 & 38,9 & 2,43 &, 30 \\
\hline 19 & $154 / 1$ & 27,4 & 6,9 & 660 & 66,3 & 5 & 22.4 & 34,7 & 97 & .35 \\
\hline 20 & $155 / 2$ & 27, & 7,2 & 584 & 39 & 1 & 11,0 & 45,2 & 13 & 0,50 \\
\hline . & $156 / 21$ & 27,6 & 7,2 & 394 & 1,5 & 0,050 & 40,3 & 41,0 & 9,72 & 0.50 \\
\hline
\end{tabular}

Tabel L-4. Hasil Uji Statistik Kualitas Airtarıah di Kutowinangun, Premburı dan Kutoarjo

\begin{tabular}{|c|c|c|c|c|c|c|c|}
\hline Paranet & Lohasi & Rerata & St, hev. & ir & $E \quad i \cdots$ & $F 1-3$ & $\because 2-3$ \\
\hline UAL. & $\left.\begin{array}{l}\text { Kutowi a } \\
\text { Prembun } \\
\text { Kutoarjo }\end{array}\right\}$ & $\begin{array}{l}625,00 \\
602,90 \\
565,05\end{array}$ & $\begin{array}{l}203,41 \\
146,99 \\
196,41\end{array}$ & $\begin{array}{l}21 \\
20 \\
21\end{array}$ & 1,910 & 1,073 & 0,561 \\
\hline $\mathrm{Cl}$ & $\begin{array}{l}\frac{1}{2} \\
3 \\
3\end{array}$ & $\begin{array}{l}50,31 \\
33,06 \\
44,10\end{array}$ & $\begin{array}{l}36,23 \\
20,73 \\
28,10\end{array}$ & $\begin{array}{l}2: \\
20 \\
21\end{array}$ & 3,032 & $1,68:$ & $.0,548$ \\
\hline $\mathrm{SO}_{2}$ & $\begin{array}{l}\frac{1}{2} \\
\frac{2}{3}\end{array}$ & $\begin{array}{l}0,0194 \\
0,0062 \\
0,0134\end{array}$ & $\begin{array}{l}0,02013 \\
0,0124 \\
0,0124\end{array}$ & $\begin{array}{l}21 \\
21 \\
21\end{array}$ & 2.846 & 2,649 & 1,001 \\
\hline $\mathrm{BO}_{3}$ & $\frac{1}{2}$ & $\begin{array}{r}4,004 \\
4,005 \\
13,340\end{array}$ & $\begin{array}{r}4,644 \\
4,344 \\
14,644\end{array}$ & $\begin{array}{l}21 \\
210 \\
21\end{array}$ & 1,140 & 0,098 & 0,086 \\
\hline $\mathrm{SO}_{4}$ & $\begin{array}{l}1 \\
2 \\
3\end{array}$ & $\begin{array}{l}21,213 \\
24,980 \\
11,486\end{array}$ & $\begin{array}{l}19,793 \\
15,839 \\
11,551\end{array}$ & $\begin{array}{l}21 \\
20 \\
21\end{array}$ & 1,558 & 2,936 & 1,385 \\
\hline 000 & $\frac{1}{2}$ & $\begin{array}{r}10,130 \\
8,622 \\
1,825\end{array}$ & $\begin{array}{l}4,297 \\
5,901 \\
2,178\end{array}$ & $\begin{array}{l}21 \\
20 \\
21\end{array}$ & 0,528 & 3,884 & 7,359 \\
\hline 800 & $\begin{array}{l}\frac{1}{2} \\
3\end{array}$ & $\begin{array}{l}1,740 \\
1,242 \\
0,684\end{array}$ & $\begin{array}{l}1,55.9 \\
0,812 \\
0,568\end{array}$ & $\begin{array}{l}21 \\
20 \\
21\end{array}$ & 1,910 & 1,073 & 0,561 \\
\hline
\end{tabular}

